\title{
The Spread of English among Saudis in the Era of Globalization: A Friend or a Foe?
}

\author{
Turki Alsolami \\ English Language Institute \\ Faculty of applied Studies \\ King Abdulaziz University \\ Jeddah, Saudi Arabia \\ Nashwa Saaty \\ English Language Institute \\ King Abdulaziz University \\ Jeddah, Saudi Arabia
}

\begin{abstract}
Through globalization, people, their life routines, ideas and social events move across borders to a larger degree than in the past. Both, the concept and the practices associated with globalization can be considered to be beneficial or threatening, to people, societies, and governments. As communication among globalists is being taking place, there has to be a language that facilitates the discourse and interaction for any globalization process. For a number of historic reasons, English has emerged as the language of globalization as well as a global language that is spoken by millions of users around the world. However, the globalization of English has its pros and cons, and researchers, particularly in the Muslim world, have a different perspective of this issue. This paper tackles issues related to English as a global language in a particular EFL context in a Muslim context.
\end{abstract}

Keywords: English, Saudi Arabia, globalization, cultural identity, English as a global language 


\section{Introduction:}

Globalization of nations is an inevitable outcome of recent technological developments and inventions that facilitate interaction at various levels - economic, political, technological, social, and cultural (Timothy, 2019). These interactions take place among countries, business firms, scholars, and individuals, and they require a common language of communication. English has been viewed by many as the language of globalization for its superiority over other languages used in international communication (Sharifian, 2016). Therefore, many countries have introduced the teaching of English in schools and universities, and in some cases, English has become a requirement for certain types of employment (Fabo, Beblavý, \& Lenaerts, 2017).

Despite the expansion of English into the lingua franca, research has documented resistance and hostility to the rapid intrusion of English into the lives of some people (Fitriati \& Rata, 2020). English is viewed as a barrier and its expansion is a threat to local cultures and communities. This perception can be intensified in the Muslim world as it may be regarded by some as a threat to a very sacred language, Arabic (Abd Rashid \& Ibrahim, 2018).

The views of the globalization of English and its impact are controversial. The literature review below offers a classification of how people view the spread of English in their respective countries. Some research studies have indicated that some people take a positive view and are openly accepting of the English language, seeing it as a necessity for modernisation. Other researchers have indicated that some people oppose its spread and view it as destructive, fearing that it will eliminate societies and languages (Hassan \& Change, 2020; Islam, 2019; Rahman et al., 2019).

This paper highlights some of these issues that are related to English as a global language in the light of the existing literature and taking Saudi Arabia as a case study. It is of particular interest for stakeholders and EFL course designers when taking into consideration sensitive elements of culture, religion and L1. Additionally, it offers a common platform for arenas of dialogue and international cooperation. 


\section{The Saudi Context}

Saudi Arabia is a monocultural and conservative Muslim country that has never been under any colonisation. The religion of Islam is a strong and vital motivating force for Saudis, and it governs all aspects of law, community behaviour, culture, and daily affairs (Alfalih, 2016; HAQ \& Smadi, 1996). In addition, Saudi Arabia presents itself as the defender of the faith in the face of a cultural and religious onslaught from the West due to its leading position in the Islamic world and having the two holiest cities for Muslims - Makah and Medina (Fandy, 1999). The Arabic language is the official language of Saudi Arabia, the language of education, media and government. Arabic has an important status in the Arab world and particularly Saudi Arabia. Arabic is the language of the holy book, and Muslims and Islamic scholars believe that the Quran is one of the reasons for preserving the language.

Saudi Arabia is the one of the youngest and wealthiest countries in the world. It is the largest oil producer and around 90 percent of its income is derived from oil. To minimize its heavy dependence on oil revenue, the Saudi government's Eighth Development Plan (2005-2009) stated that its vision was for:

" a diversified and prosperous economy that ensures a supply of rewarding job opportunities and economic welfare to all citizens, provides good quality education and healthcare to the population, and helps manpower acquire the necessary skills while maintaining the Kingdom's Islamic values and cultural heritage".

Saudi Arabia has experienced a profound and rapid social change as well as economic growth, and these have been accompanied by modernisation in many fields of life including education, medical care, welfare, and individual lifestyles (Elyas, 2008). This new trend has entailed a knowledge transfer from other cultures, especially developed Western countries (HAQ \& Smadi, 1996). The determination of the Saudi government to pursue economic and technological development has continued, and this was evidenced in 2004 when it initiated a five-year scholarship program for Saudis to pursue their education in countries around the globe. This arrangement is called the King Abdullah Scholarship Program (KASP). In 2009, 
KASP was extended for another five years. The plan is to send more than 100000 students for undergraduate and postgraduate studies in different fields of study to more than 14 countries in North America, Australia, Asia and Europe. However, the focus has been heavily on sending students to the USA. One of the main objectives of the program is to exchange education and culture with other parts of the world in order to create a new generation with a western-based education who will transfer knowledge and be part of the transformational phase of the country to diversify its economic base (Ministry of Higher Education, 2010).

\section{English in Saudi Arabia}

English features in public life in Saudi Arabia as a semi-official language, often in tandem with Arabic (Moody, 2009). According to Kachru (1992) model, Saudi Arabia would be considered as one of the "expanding countries circle" where English still has a foreign language status. The spread of English can be seen from the high number of expatriates who work in Saudi official and from the non-official establishments where they use English as the communication language (HAQ \& Smadi, 1996). Signs and public notices are common in both languages. Radio and television have English programs, and there are at least two English-language newspapers in most countries, intended mainly for English-speaking expatriates but increasingly read by L1 Arabic speakers (Elyas, 2008).

Since the mid-1700s most major scientific and technological research has been reported in learned English-language journals, and so, for countries that wished to adopt modern scientific developments the study of that language become a priority in the educational agendas of non-native English speaking countries (Jung \& Norton, 2002). In Saudi Arabia, too, educational policymakers realized the significance of English as a global language of communication. The learning of English is currently accorded priority in the Saudi 
educational system; it is the only foreign language taught in schools and is a core introductory course for all majors in all Saudi universities (Barnawi \& Al-Hawsawi, 2017).

English was identified as a powerful tool to facilitate the course of modernisation of the country (Karmani, 2005), and the introduction of English teaching in the Saudi educational system was a response to a demand both by government and by public need (Alrabai, 2018). Indeed, as early as 1930 English was introduced to the school curriculum and became the first foreign language incorporated into the Saudi primary education system (Al-Hazmi, 2017). A reorganization of the Saudi educational system in 1942 resulted in English being taught at higher levels too, and it became one of the subjects taught in the newly established intermediate and secondary schools. Initially, English language occupied four lessons in the weekly timetable of intermediate and advanced public schools, but later this was increased to six classes per week. English was fully incorporated into the curriculum of all primary schools in 2003 (Elyas, 2008).

The recent expansion of the teaching of English in Saudi Arabia has been rapid.The programs are intensive and may occupy between 20-25 hours each week. Many universities entered a race to recruit English-language teachers, buy international textbooks, and obtain the latest technologies that support teaching and learning.

\section{Perspectives on Globalization and the Spread of English}

English has emerged as the hegemonic language in the contemporary world, due both to the extensive impact of the British Empire during the colonial period and to the dominance of the American economy, culture, science, technology, and politics (Gordin, 2017). English has become the lingua franca of interaction. English is the mean of communication in air traffics and used in sciences, technology as well as the main language for music, movies, and advertising, and it is also the language of international entertainment activities e.g. tourism (Hopkyns, 2014). Over 80 percent of all information of the materials on the internet are written in English. The number of speakers of English (native and non-native is estimated in millions and growing (Crystal, 1995). 
Pennycook (1999) offered a rationalization for the rise of English as a global language. Firstly, it may be attributed to a colonial celebration that viewed the globalization and dominance of English as a reflection of its superiority over other languages. Secondly, the rise of laissez-faire liberalism which views the spread of English is a positive benefit because it can coexist harmoniously with other languages Thirdly, language ecology whereby English is perceived as a global language which threatens the survival of other languages. Fourthly, linguistic imperialism, where the dominance of English is perceived to be an extension of political and economic imperialism (Phillipson, 2016).

Held (1999) classified perspectives of globalization into three groups, hyperglobalist, sceptical, and transformationalist. According to the hyperglobalist concept, globalization is viewed as a new epoch of human history where traditional nations states and business units merge into a global economy. According to this theory, globalization will bring 'denationalization' of economies through the establishment of borderless networks of production, trade and finance and where it is driving the construction of new economic, social, and political world orders, leading ultimately to greater overall homogeneity (Held, 1999). On the other hand, the sceptical view of globalization is that the current levels of economic interdependence are by no means historically unprecedented or inevitable, for national governments still exist to regulate trade and power (Held, 1999). The transformationalist view is that globalization is the central driving force behind the rapid social, political and economic changes that are reshaping societies and the world order (Held, 1999).

Following Held's work, Dewey (2007) adopted the same conceptualizations to describe the perspectives of the spread of English in the world. The hyperglobalist framework can correspond to linguistic imperialism and notions of international English hegemony. The sceptical view is that English can continue to be taught in according to the native-speakers' norms with no apparent threats or need for further change. The transformationalist view considers that languages are reshaping the world order in accordance with the socio-political 
movements

that

are taking

place.

\section{Globalization and Cultural Identity}

There is a common agreement that the world is becoming culturally globalised by continuous, increasing, and deepening flows of goods, people, capital, ideas, and information across national boundaries (Hopkyns, 2014). The facts that people across the globe are watching the same programs and that international restaurants are opening throughout the world are indisputable evidence of the globalization.

The discourse regarding the merits of globalization is a controversial issue in Saudi Arabia, as indeed it is in many other countries. There are some who affirm that globalization has become a reality which provides benefits, but conversely others assert that globalization is leading to the cultural domination of Western values over their own traditional values (Saudi Gazette, 2010). Most critics of globalization are sceptical of the benefits and advantages, citing the unknown implications of globalization on their Islamic lifestyles. Proponents, on the contrary, view globalization from a hyperglobalist or a transformationalist perspective. Tomlinson (2003) rightly states that: "cultural identity is a not a fragile communal, psychic attachment, but a product of deliberate cultural construction that is maintained by regulatory and socialising institutions on the state" (p271). He maintains that globalization proliferates identities rather than destroys them by interaction with other cultures that enables individuals to enhance their knowledge of others.

\section{The Impact of English in Saudi Arabia: The ongoing Debate}

The spread of English across Saudi Arabia has been unsettling for a number of researchers (Ahmed Alsisy \& Abdullah Alsewiket, 2020; Elyas, 2008; HAQ \& Smadi, 1996; Karmani, 
2005). Their research findings have showed different views and perspectives of how the rise of English as a global language has impacted Saudis positively or negatively.

Karmani (2005) believe that the teaching of English nowadays is a tool used in the Muslim countries that would lead to a de-Islamisation of Islamic nations. He believes that the rise of English in Muslims countries has a hidden agenda, namely: "less Islam and more English". This notion is supported on three grounds. In a response to Karmani (2005), Elyas (2008) argues that these claims are based on Karmani's personal observations regarding the Western media and that no empirical studies have been conducted to support such views.

Arabic is a sacred language for Saudi Muslims and its existence and protection is rooted in the fact that it is the language of the Quran. Moreover, Karmani (2005) notes that there have been concerns that the huge investment in, and spread of English-language education, that included language centres and highly-paid English teachers has led to a perception that the Arabic language is not the language that could meet global challenges. Karmani (2005) seems to be sceptical that this expansion would lead to the Anglicisation of education at the expense of Arabic. The voice of Arabic scholars who have been calling for the translation of all knowledge into Arabic rather than English seems contrary to the wave of change that is spreading across the world, and as Elyas (2008) has rightly explained, it is necessary to accept the fact that "English is here to stay".

The investment in the English language has not only applied to education, trade, technology, and the economy, but it also involves the media. Many English-speaking channels have been established in Saudi Arabia and in the region to broadcast to the entire Middle East. These channels extensively broadcast American media products such as movies, sitcoms, music and news. In addition, the domination of English on most popular websites is a means whereby Saudis can learn to read and write in English and be part of the globalised world using the language of globalization. Karmani (2005) warns that the constant exposure to English would lead to what he called "cultural alienation". 
English-language education entails the exposure of learners to the culture of Englishspeaking countries. Mastering different languages has many cultural advantages for both individuals and the community. Access to other languages enables people to be more flexible and aware of other cultures and points of view, and people who speak more than one language tend to be more accepting of other ethnic groups and cultures. Elyas (2008) found that the majority of Saudi students majoring in English oppose the idea of separating the learning of English and the culture of English and do not see English as a threat to their cultural identity. Rather, they consider it to be a language of communication that is becoming essential for many forms of employment, travel, and business. However, some elements of Western culture permit drinking alcohol and dating, practices that are considered taboo in some Muslim countries such as Saudi Arabia. Al-Asmari (2008) states that there are constraints to introducing English culture into classrooms, and these include establishing 'red lines' around sensitive aspects of Saudi culture. This has been described as ethnocentrism, and in the context of Saudi Arabia it may be considered to be a form of 'cultural sheltering'.

Learning a language is not simply the learning of the grammar and the lexis but entails absorption of its culture, customs, and beliefs. Crystal (1995) asserts that English imposes its cultural background on the mind of its learners. Mohd-Asraf (2005) expresses the position of some Muslim scholars in opposing the teaching of English culture as it may lead students to become westernized or to adopt secular values which contradict the Islamic faith. They argue that English to be taught nothing more than a linguistic means to certain ends.

As the command of English in non-English-speaking countries can create opportunities, the lack of English can create problems. The Saudi government has called on the private sector to employee more Saudis, especially high school graduates, to replace foreigners. Some of these companies have a global connection and require English proficiency, both spoken and written. However, the lack of English by many young people may have contributed to a relatively high level of youth unemployment in Saudi Arabia because many corporations use English as their first language of communication. As in many other countries, the adoption 
of English seems to be unavoidable in the Arab world, including Saudi Arabia, and people just have to deal with it.

As Elyas (2008) states:

"English is here to stay, but the people are reshaping, remoulding, and adjusting it to suit them best. Hence, it will be interesting to see whether the Arab world will adapt its own version of the English language, or embrace the present one together with its cultural and social norms"

(p. 46).

\section{Conclusion:}

It can be said that the teaching of English in Saudi as a global language has not yet conceptualized its position in the country as the language of communication that goes side by side with Arabic. However, the globalisation of Saudi Arabia requires that English should be taught in schools and given emphasis, despite the sceptical views on its impact on the cultural identity. English is viewed by many non-English speaking contexts in the world as a global language that is used in various aspects of life and business. 


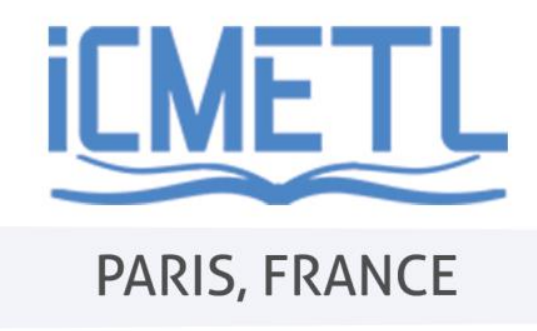

20-22 NOVEMBER, 2020

\section{References}

Abd Rashid, R. S. A., \& Ibrahim, E. H. E. (2018). English language textbooks and portrayal of culture: A content analysis. Paper presented at the MATEC Web of Conferences.

Ahmed Alsisy, G., \& Abdullah Alsewiket, A. J. I. (2020). Persectives of Academic Staff and Graduate Students on the Effects of Globalization on Cultural Identity in Saudi Arabia: A case Study. 36(4), 1-36.

Al-Asmari, M. (2008). Saudi labor force: Challenges and ambitions. J JKAU: Arts and Humanities, 16(2), 19-59.

Al-Hazmi, S. J. J. o. M. L. (2017). Current issues in English language education in the Kingdom of Saudi Arabia. 17(1), 129-150.

Alfalih, A. (2016). Religion, culture and management: a comparative study of the impact of Islam and Saudi culture on HRM practices of indigenous and foreign owned and managed corporations in Saudi Arabia.

Alrabai, F. (2018). Learning English in Saudi Arabia. J English as a foreign language in Saudi Arabia: New insights into teaching learning English, 102-119.

Barnawi, O. Z., \& Al-Hawsawi, S. (2017). English education policy in Saudi Arabia: English language education policy in the Kingdom of Saudi Arabia: Current trends, issues and challenges. In English language education policy in the Middle East and North Africa (pp. 199-222): Springer.

Crystal, D. (1995). The Cambridge Encyclopedia of the English Language Text.

Dewey, M. (2007). English as a lingua franca and globalization: an interconnected perspective. J International Journal of Applied Linguistics, 17(3), 332.

Elyas, T. (2008). The attitude and the impact of the American English as a global language within the Saudi education system. J Novitas-Royal, 2(1), 28-48.

Fabo, B., Beblavý, M., \& Lenaerts, K. J. E. (2017). The importance of foreign language skills in the labour markets of Central and Eastern Europe: assessment based on data from online job portals. 44(3), 487-508.

Fandy, M. (1999). The history of Saudi Arabia. J Islam Christian Muslim Relations, 10(3), 411.

Fitriati, S. W., \& Rata, E. (2020). Language, Globalization, and National Identity: A Study of English-Medium Policy and Practice in Indonesia. J Journal of Language, Identity and Education, 1-14.

Gordin, M. D. J. I. (2017). Introduction: Hegemonic languages and science. 108(3), 606-611.

HAQ, F. A. A. A., \& Smadi, O. (1996). Spread of English and westernization in Saudi Arabia. $J$ World Englishes, 15(3), 307-317.

Hassan, I. J. I. J. o. I., Creativity, \& Change. (2020). English Language Learning, Environment, and the Formation of Islamic Self-identity among Students in Selected Religious Secondary Schools. 11(7).

Held, D. (1999). The transformation of political community: rethinking democracy in the context of globalization. 


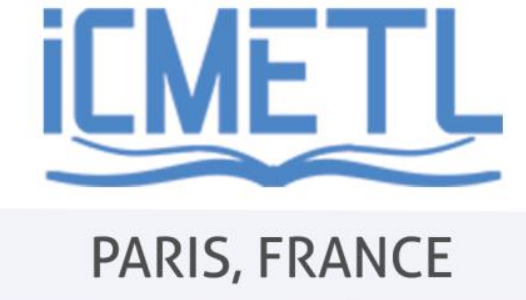

20-22 NOVEMBER, 2020

Hopkyns, S. (2014). CHAPTER ONE AConflict OF DESIRES: ENGLISH AS A GLOBAL LANGUAGE AND ITS EFFECTS ON CULTURAL IDENTITY IN THE UNITED ARAB EMIRATES. J Issues in English education in the Arab world, 6.

Islam, M. J. P. V. (2019). National and Collective Interests Motivating English Language Learners in a Pakistani Context. 20(1).

Jung, S., \& Norton, B. (2002). Language planning in Korea: The new elementary English Program. Tollefson, J.(Ed.), Policies in education: Critical issues (pp. 245-265). In: Mahwah, NJ: Lawrence Erlbaum.

Kachru, B. B. (1992). Models for non-native Englishes. J The other tongue: English across cultures, 2, 48-74.

Karmani, S. (2005). Petro-linguistics: The emerging nexus between oil, English, and Islam. $J$ Journal of language, Identity, and Education, 4(2), 87-102.

Mohd-Asraf, R. (2005). English and Islam: A clash of civilizations? J Journal of language, Identity, and Education

Education, 4(2), 103-118.

Moody, J. (2009). A neglected aspect of ELT in the Arabian Gulf: Who is communication between. Paper presented at the Englishes and literatures-in-English in a globalized world: Proceedings of the 13th International Conference on English in Southeast Asia.

Pennycook, A. J. T. q. (1999). Introduction: Critical approaches to TESOL. 33(3), 329-348.

Phillipson, R. J. J. f. C. E. P. S. (2016). Native speakers in linguistic imperialism. 14(3), 8096.

Rahman, M. M., Islam, M. S., Karim, A., Chowdhury, T. A., Rahman, M. M., Seraj, P. M. I., \& Singh, M. K. M. J. L. T. i. A. (2019). English language teaching in Bangladesh today: Issues, outcomes and implications. 9(1), 9.

Sharifian, F. J. K. T. A. J. o. H. (2016). " Glocalisation" of the English Language: A Cultural Linguistics Perspective. 23.

Timothy, D. J. (2019). Globalization: the shrinking world of tourism. In Handbook of Globalization and Tourism: Edward Elgar Publishing.

Tomlinson, B. (2003). Developing materials for language teaching: A\&C Black. 